\title{
Similarities of lean manufacturing approaches implementation in SMEs towards the success: Case study in the automotive component industry
}

\author{
Rose, A.N.M ${ }^{1}$, Ab Rashid, M.F.F ${ }^{1}$, Nik Mohamed, N.M.Z' ${ }^{1}$, Ahmad, H. $^{2}$ \\ ${ }^{1}$ Faculty of Mechanical Engineering, Universiti Malaysia Pahang, 26600 Pekan, Pahang, Malaysia \\ ${ }^{2}$ TATI University College, 24000 Kemaman, Terengganu, Malaysia
}

\begin{abstract}
Nowadays, manufacturing companies are striving for a better system like lean manufacturing (LM). The primary objective of LM is to identify and eliminate wastes. LM can be applied successfully in all industries providing a full understanding of lean ingredients i.e. concept, principles, and practices. There are a lot of practices which are necessary to be implemented in order to gain full benefits of LM. However, small and medium enterprises (SMEs) are lack of knowledge in LM and facing difficulties to adopt all of the LM principles. Therefore, it is necessary to the researchers to come out with a simple guideline for LM implementation. The objective of this paper is to explore the journey of LM implementation including preliminary, in process and post of LM. This research was conducted through multi-case study research. There were four SMEs and two large companies. The gathered information shows that the preliminary stage of LM implementation is similar to each other including large companies. The result shows SMEs still have a potential to success in LM. This finding might give an opportunity to SMEs to prepare the basis for LM implementation effectively. As a result, SMEs able compete in the competitive global marketplace and strive for world class performance through implementation of LM.
\end{abstract}

\section{Introduction}

Today, Small and Medium Enterprises (SMEs) can be considered as the backbone of an economy. SMEs are among the suppliers of goods and services to large companies. The challenging economy has forced SMEs to become more responsive and flexible in operational, tactical and strategic areas. In order to survive nationally and internationally, SMEs need to produce high-quality products at competitive prices. Hence, globalization has lead companies to find the right management system to improve current performance. According to [1]Rineheart et al., Lean Manufacturing (LM) will be the standard management system of the $21^{\text {st }}$ century. It will be acceptable and adaptable to all industries. The main advantage of LM is its ability to reduce production cost through elimination of wastes, and if well implemented, it can assist a company to become a world-class organization [2]. The elimination of wastes has given a substantial impact on manufacturing companies, resulting in higher performance enhancement and significant improvement in delivery, quality, flexibility and manufacturing cost [3]. Researchers and practitioners widely knew the benefits of LM after the book titled "The machine that changed the world" is published [4]. Later, LM became an established field of research. The majority of past studied had concentrated their investigation on lean performance, lean indicators and lean implementation [5],[6],[7],[8]. Farris et al. [9] have investigated the importance of critical success factors for effective and successful LM implementation. Up till now, the majority of LM researchers were focusing on large companies, and little has been researched on SMEs [8],[6],[10]. The objectives of this study are to explore the early preparation and ongoing development activities for LM implementation. Apart from that, this study also would like to explore the benefits and barriers of LM application. This was due to many implementations to date were based on trial and error. The study shows that most of the companies were applying same practices and follow similar steps towards the success.

\section{Literature review}

LM can be applied effectively with a strategic and systematic approach [11]. Therefore, the implementation and selection of the right LM practices must be based on knowledge and experience [12]. Currently, there are many of LM practices available and being practiced by the practitioner [13]. The company should prioritize and decide which practice to start first [14]. Large company do not have any difficulties and constraint in adopting LM practices and are likely to implement all of the LM practices, unlike SME [15]. Therefore, SMEs are encouraged to start with the feasible LM practices such as $5 \mathrm{~S}$, multifunction, continuous improvement and reduction in setup time [14][16][17]. These practices are considered simple, easy, least investment and able to be managed internally. Understanding and guidance on lean practices implementation are very crucial to SMEs. The top management and responsible person need to know how to get started, where to start and how to proceed [18]. Therefore, in this paper, the authors would like to identify the route to success for SMEs to implement LM such as early preparation for the appointment of steering committee, team formation and also the selection of production line which applies to them. A comprehensive literature review on LM enables the authors to categorize LM practices into three groups based on company size, piecemeal practices and number of years with established LM [15],[17],[16]. Piecemeal practices are those can be applied independently such as $5 \mathrm{~S}$, preventive maintenance and multifunction employees. Thus, the SMEs should take into consideration their ability before embarking on LM. Rose et al. [14] have proposed three categories of LM practices; basic, intermediate and advanced. This perhaps will assist SMEs to use it as a guide for LM implementation and 
will also overcome difficulty factors in LM implementation, such as lack of understanding and wrong methodology [19]. Various studies have been carried out on LM practices, such as based on lean bundles, company sizes, operation performance, infrastructure and location, but none of them discussed on feasible practices [20], [21],[7],[22],[17], [23]. The study of LM in Malaysia is still limited [24] and it is an excellent opportunity for researchers to explore on how LM can be implemented here. Apart from LM practices, the company also need to consider on early preparation, best implementation and evaluation [18]. Therefore in this study, the authors would like to explore the stage of preparation on LM implementation including focusing on feasible practices. In addition, the authors also try to highlight the significant activities need to be implemented in order to ensure the LM is succeeded.

\section{Methodology}

This research was conducted by using multi-case study. One of the advantages of case study research can examine how and why to the key personnel that involves in the research area [25]. The main difference of case study from other methods is that it is not sampling research [26]. In this research, six case study companies were investigated. The advantage of multi-case studies can provide robustness and compelling data as compared to a single case study [27]. Also, multi-case studies can generate a replication logic which could not be produced by a single case study. And it is good for comparison purposes [28]. Therefore, the authors confident that this methodology could provide good research to investigate and compare the distinguish characteristics of LM implementation among the multi-case studies.

The case study protocol was developed for interview purpose. The purpose of this protocol is to ensure the information is consistently asked without bias. In this protocol, the structured questions were design based on LM practices, preliminary preparation on LM, benefits and barriers. It also contains the overview of the case

Table1. Companies background study, project including objectives, LM issues and relevant findings on LM implementation as prescribed by Yin [29]. All proposed LM practices were based on comprehensive literature. This protocol could be one of the methods to ensure the reliability is maintained [30]. On the validity of information, the first gathered information through first case study will be used as a reference for the next case study. This replication logic based on the first case study in the next case study could be considered as part of external validity [30].

The six companies were selected based on the list of the respondent that show interest during last survey questionnaire which was conducted earlier. All companies were informed within two weeks before the visits and also emailed a case study protocol for early preparation. These will give enough time for preparing and reserving their time for the visits. The interviews were conducted with LM coordinator and production managers. All transcribed information were checked immediately by the interviewee, as to ensure all recorded data are correct and genuine. Besides the interviews, observations were also carried out on documents, notice board, poster, and company environment. The details of company name are treated confidentially. In this paper, the companies are known as Company A, B, C, D, E and F.

\section{Company background}

Table 1 shows the summary of case study companies. There were four SMEs and two large companies. All companies are automotive component background. Most of the case study companies implemented LM in the second trial since the first trial was failed due to poor commitment from top management and employees. All companies were established more than 20 years but are considered new in LM implementation with 4 to 5 years experiences especially SMEs. However, large companies have implemented LM to more than ten years.

\begin{tabular}{|c|c|c|c|c|c|c|}
\hline & $\begin{array}{c}\text { Company } \\
\text { A }\end{array}$ & $\begin{array}{c}\text { Company } \\
\text { B }\end{array}$ & $\begin{array}{c}\text { Company } \\
\text { C }\end{array}$ & $\begin{array}{c}\text { Company } \\
\text { D }\end{array}$ & $\begin{array}{c}\text { Company } \\
\text { E }\end{array}$ & $\begin{array}{c}\text { Company } \\
\text { F }\end{array}$ \\
\hline Trial & 2 & 1 & 1 & 2 & 2 & 2 \\
\hline Type of product & Interior & Metal & Mechanical & Metal & Mechanical & $\begin{array}{l}\text { Electronic/ } \\
\text { Mechanical }\end{array}$ \\
\hline Age (year) & 39 & 22 & 49 & 27 & 35 & 35 \\
\hline Lean establishment (year) & 4 & 5 & 5 & 5 & 12 & 17 \\
\hline Ownership & Local & Local & Local & Local & Local & Foreign \\
\hline Size & SME & SME & SME & SME & Large & Large \\
\hline MAJAICO & $\begin{array}{l}\text { Member } \\
(2011)\end{array}$ & $\begin{array}{l}\text { Member } \\
(2009)\end{array}$ & $\begin{array}{l}\text { Member } \\
(2009)\end{array}$ & $\begin{array}{l}\text { Member } \\
(2009)\end{array}$ & $\begin{array}{l}\text { Model } \\
(2006)\end{array}$ & $\begin{array}{l}\text { Model } \\
(2007)\end{array}$ \\
\hline
\end{tabular}

All case study companies started LM from Malaysia Japan Automotive Industries Cooperation (MAJAICO). This cooperation is under the MalaysiaJapan Economic Partnership Agreement, which was signed in July 2006. The objective of MAJAICO is to inculcate, develop and improve Malaysian automotive companies to become more competitive as manufacturer players. One of the MAJAICO's objectives is to promote LM in Malaysian automotive operation. Two companies, $\mathrm{E}$ and $\mathrm{F}$ were recognised 
as LM model companies. The new company can learn and get advice from these two companies on any LM matters. All case study companies are local except one company is considered foreign which headquarter is in Japan. They are certified ISO9001 and TS16949. In brief, Company $\mathrm{A}$ is SME that manufactures the interior parts of a car. This is the second trial on LM implementation. The objective of Company A in LM application is to maximize company's profit. Company $\mathrm{B}$ is also under SME category and it is the first time in LM implementation. This company produces metal parts. Company B is very confident in LM ability towards the elimination of wastes. Company $\mathrm{C}$ is also considered as SME. This company manufactures mechanical parts. The interviews show this company is very committed to LM implementation. Company D is also SME. This company produces metal parts. The main reason for implementing LM is to maximize profits through reduction of operation cost included the elimination of wastes. This is a second time for LM implementation. The first time implementation failed due to poor employees' commitment and lack of knowledge on LM. There are two large companies in this case study for comparison purpose, Company $\mathrm{E}$ and F. Company E produces mechanical parts. This company has implemented LM twice. Again the same problems occurred on the failure of LM implementation due to lack of employees' commitment and lack of knowledge. Company $\mathrm{F}$ is a large company and is considered as foreign ownership. This company produces electronic and mechanical parts. According to the person in charge in LM, the first trial implementation was failed due to the management not serious in LM application. Despite of economy quite slow in the year of 1998, the top management insisted LM implementation as part of strategies to eliminate production wastes.

\section{Discussion}

Multiple case studies were designed to explore the similarity approaches which were carried out by the case study companies in LM implementation. During these investigations, the researchers discovered the similarities on the initial implementation, LM activities, relevant issues, benefits and challenges in LM implementation. Table 2 shows the summary of activities that were carried out by the case study companies. All case study companies were applying similar activities starting from basic activities such as the formation of steering committee and formation of LM unit as highlighted in Table 2.

Table 2. Lean Manufacturing implementation in case study companies

\begin{tabular}{lcccccc}
\hline Particulars & Company & Company & Company & Company & Company & Company \\
& A & B & C & D & E & F \\
\hline Basic & & $\sqrt{ }$ & $\sqrt{ }$ & $\sqrt{ }$ & $\sqrt{ }$ & $\sqrt{ }$ \\
Formation steering committee & $* \sqrt{ }$ & $\sqrt{ }$ & $\sqrt{ }$ & $\sqrt{ }$ & $\sqrt{ }$ & $\sqrt{ }$ \\
Formation unit of LM & $\sqrt{ }$ & $\sqrt{ }$ & $\sqrt{ }$ & $\sqrt{ }$ & $\sqrt{ }$ & $\sqrt{ }$ \\
Incentive scheme & $\sqrt{ }$ & $\sqrt{ }$ & $\sqrt{ }$ & $\sqrt{ }$ & $\sqrt{ }$ & $\sqrt{ }$ \\
Formation of LM team & $\sqrt{ }$ & $\sqrt{ }$ & $\sqrt{ }$ & $\sqrt{ }$ & $\sqrt{ }$ & $\sqrt{ }$ \\
Production line selection & & & & & & \\
\hline
\end{tabular}

LM could not run successfully without a steering committee. In this study, all case study companies have started with the formation of steering committee. This committee comprised of top management including production manager, quality manager and sales manager led by the senior manager. The function of this committee is to develop policy, budget, resources and company direction based on LM. Even, they should always support the LM team and employees on obstacle matters. To support LM implementation, all case study companies agreed that the formation of LM unit is a must for better coordination purpose. Most of the case study companies appointed LM coordinator for coordinating LM implementation including training arrangement. Company A, D, E and F have experienced on the failure of LM due to no dedicated unit is assigned for LM management. Most of their employees were discouraged due to lack of morale support and motivation from top management on LM implementation. Therefore, the company who want to success in LM implementation should always motivate their employees through providing an incentive scheme which able to boost the employee initiative in LM activities. All case study companies confirmed that they are providing incentive scheme to their employees who involved in LM in term of financial, recognition, free parking and present such as hamper. All companies agreed that the company should select a production line as a model for LM implementation. In this study, all case study companies started with a production line which has a significant problem on wastes. Company A, C, and D had chosen the production line which has high work in progress. However, Company B, E, and F decided the line which has high lead time. Then, the successful approaches in this production line will be applied to another production line. This approach could increase the employee's spirit and able to motivate them to run LM effectively.

On the LM implementation, most of the case study companies were implemented same practices such as $5 \mathrm{~S}$, continuous improvement, reduce set up time, visual display, value stream mapping, cell layout and improvement team as tabulated in Table 3. 
Table 3. Preliminary implementation of lean manufacturing

\begin{tabular}{lcccccc}
\hline \multicolumn{1}{c}{ Company } & A & B & C & D & E & F \\
\hline 5S & $\sqrt{ }$ & $\sqrt{ }$ & $\sqrt{ }$ & $\sqrt{ }$ & $\sqrt{ }$ & $\sqrt{ }$ \\
Continuous improvement & $\sqrt{ }$ & $\sqrt{ }$ & $\sqrt{ }$ & $\sqrt{ }$ & $\sqrt{ }$ & $\sqrt{ }$ \\
Reduce set up time & $\sqrt{ }$ & $\sqrt{ }$ & $\sqrt{ }$ & $\sqrt{ }$ & $\sqrt{ }$ & $\sqrt{ }$ \\
Visual display & $\sqrt{ }$ & $\sqrt{ }$ & & $\sqrt{ }$ & $\sqrt{ }$ & $\sqrt{ }$ \\
Value stream mapping & $\sqrt{ }$ & $\sqrt{ }$ & $\sqrt{ }$ & $\sqrt{ }$ & $\sqrt{ }$ & $\sqrt{ }$ \\
Improvement team & $\sqrt{ }$ & $\sqrt{ }$ & $\sqrt{ }$ & $\sqrt{ }$ & $\sqrt{ }$ & $\sqrt{ }$ \\
Cell layout & & $\sqrt{ }$ & $\sqrt{ }$ & & $\sqrt{ }$ & $\sqrt{ }$ \\
\hline
\end{tabular}

$5 \mathrm{~S}$ is considered the key to success in LM implementation [31]. It is a good starting point for $5 \mathrm{~S}$ implementation in a selected production line. All interviewees highlighted that $5 \mathrm{~S}$ implementation is easy and feasible to be applied, provided all employees are very serious and committed. Through $5 \mathrm{~S}$, all problems are visible compared to before $5 \mathrm{~S}$ implementation. Like Company $\mathrm{C}$, their workers are happy with the new environment which is clean and very tidy. Apart from that, all case study companies managed to reduce searching time on their tools when needed. Next practice which was highlighted very important is continuous improvement. The company should encourage their employees to implement continuous improvement through suggestion scheme. Continuous improvement can be in any activities as long it could provide benefits to the company and employees. Good and feasible suggestion will be rewarded as approved in the incentive scheme. Company A and Company B similarly provides an incentive scheme to a good suggestion by giving a certain amount of cash per suggestion. Other than financial scheme, Company $\mathrm{E}$ has provided a special parking lot for employees who give an excellent suggestion.

Table 4 shows the benefits gained by the case study companies. Most of these companies can identify nonvalue added activities through VSM. Like company A and $\mathrm{B}$ could reduce waiting time by $10 \%$ after reallocating inspection area. In average the case study companies able to reduce lead time by $10 \%$ to $15 \%$ through set-up time reduction. All activities and achievement were displayed in notice board. Indirectly, this information could motivate the employees to implement LM especially when there is some improvement on the action taken. Similarly, sharing information through notice board is also practiced in the ceramic company for displaying their quality achievement [32].

Table 4. The benefits of lean manufacturing

\begin{tabular}{|c|c|c|c|c|c|c|}
\hline Particulars & $\begin{array}{c}\text { Company } \\
\text { A }\end{array}$ & $\begin{array}{c}\text { Company } \\
\text { B }\end{array}$ & $\begin{array}{c}\text { Company } \\
\text { C }\end{array}$ & $\begin{array}{c}\text { Company } \\
\text { D }\end{array}$ & $\begin{array}{c}\text { Company } \\
\text { E }\end{array}$ & $\begin{array}{c}\text { Company } \\
\text { F }\end{array}$ \\
\hline Reduced inventory & & $\sqrt{ }$ & $\sqrt{ }$ & $\sqrt{ }$ & $\sqrt{ }$ & $\sqrt{ }$ \\
\hline $\begin{array}{l}\text { Reduced floor space utilization } \\
\text { Reduced lead time }\end{array}$ & $\begin{array}{l}\sqrt{ } \\
\sqrt{ }\end{array}$ & $\sqrt{ }$ & $\sqrt{ }$ & $\sqrt{ }$ & $\begin{array}{l}\sqrt{ } \\
\sqrt{ }\end{array}$ & $\begin{array}{l}\sqrt{ } \\
\sqrt{ }\end{array}$ \\
\hline Delivery on time & $\sqrt{ }$ & $\sqrt{ }$ & $\sqrt{ }$ & & $\sqrt{ }$ & $\sqrt{ }$ \\
\hline Increased productivity & $\sqrt{ }$ & $\sqrt{ }$ & $\sqrt{ }$ & $\sqrt{ }$ & $\sqrt{ }$ & $\sqrt{ }$ \\
\hline Effective cash flow & & $\sqrt{ }$ & & & $\sqrt{ }$ & $\sqrt{ }$ \\
\hline Increased quality & & $\sqrt{ }$ & $\sqrt{ }$ & & $\sqrt{ }$ & $\sqrt{ }$ \\
\hline
\end{tabular}

All companies agreed that the highest achievement benefits from LM implementation are reduced inventory, lead time, increase productivity and deliver on time. The improved percentage of inventory was discovered about $20 \%$ to $40 \%$. Apart from that, the lead time also has improved from $40 \%$ to $50 \%$. As a result, their productivity has increased about $20 \%$ to $30 \%$. However, some companies did not gain the benefits of floor space utilization due to still under transition period. They were focusing on inventory management and lead time reduction. Frequent delivery arrangement to the customer. Like Company $\mathrm{B}$ has planned two trips morning and afternoon for customer delivery. If missed delivery, the production manager has to check and find out what's wrong with the production. By practicing good practice, the company able to monitor and control the production plan effectively. Thus, their cash flow improved when the inventory is maintained at the minimum level compared to previously. 
Table 5. The barriers of lean manufacturing implementation

\begin{tabular}{lcccccc}
\hline Particulars & Company & Company & Company & Company & Company & Company \\
& A & B & C & D & E & F \\
\hline Frequent quit the job & $\sqrt{ }$ & $\sqrt{ }$ & $\sqrt{ }$ & $\sqrt{ }$ & $\sqrt{ }$ & $\sqrt{ }$ \\
Lack of employee involvement & $\sqrt{ }$ & $\sqrt{ }$ & $\sqrt{ }$ & $\sqrt{ }$ & $\sqrt{ }$ & $\sqrt{ }$ \\
Lack of knowledge in LM & $\sqrt{ }$ & $\sqrt{ }$ & $\sqrt{ }$ & $\sqrt{ }$ & $\sqrt{ }$ & $\sqrt{ }$ \\
Organisation culture & $\sqrt{ }$ & $\sqrt{ }$ & $\sqrt{ }$ & $\sqrt{ }$ & $\sqrt{ }$ & $\sqrt{ }$ \\
Lack of employee commitment & & & &
\end{tabular}

All case study companies claimed that five barrier factors that caused the failure of LM implementation as highlighted in Table 5. These factors are high employee turnover, lack of employee involvement, lack of knowledge in LM, organization culture and lack of employee commitment. One of the reasons employees keep changing the job is due to better offers from other company. Despite this, the companies have to retrain new employees on LM implementation. This factor has caused the companies have to spend money and time twice on the same activities. The companies agreed that the training is very importance to be provided to their employees including top management. Most of them revealed that their employees were unmotivated on LM due to lack of understanding on the LM concept and practices.

Additionally, this factor causes poor employees commitment to the LM implementation, especially when the current system has to change to a better system such as using pull system. However, they were still practicing the old system. The challenge of employee commitment is they do not understand the LM system. The case studies have shown that the training on LM is considered compulsory to employees and top management. Through systematic training, the employees able to foreseen the potential improvement included the contrasting between LM and the current system.

Apart from that, the observation and interviews also discovered the importance of regular meeting and follow up on LM implementation. These activities could overcome any facing problem in the premise due to LM. All responsible persons have to report on LM achievement and problems in the meeting. Normally all problems engagement are solved in the meeting. One of the interviewees highlighted the meeting could motivate their employees and also overcome the problem which affects the process of LM implementation. Therefore, it is good to a new company to consider the LM practices, early preparation and LM activities as were carried out by the case study companies in order to ensure LM could be effectively implemented.

\section{Conclusion}

The multi-case studies have explored the successful of LM implementation in SMEs. Apart from that, this method also highlighted the benefits and barriers along the journey of LM implementation. It is challenging part for SMEs to overcome the barriers, especially on employees' loyalty. Initially, the planning and executing on LM preparation are almost the same. However, some companies have implemented and developed based on their environment as to suit with the production requirement. The LM implementation should not copy exactly as the successful company did but they need to adopt and adapt based on their needs.

The comparison between SMEs and large companies on LM approaches looks similar, but the way of implementation depends on their uniqueness and creativity. All case study companies agreed that the LM could reduce their inventory to the minimum level by ensuring all wastes are eliminated accordingly. The case study companies still not satisfied with the current achievement. It is due to most of them are considered new and still at early stage of LM, compared to established company like Toyota Motor. Therefore, they are eagerly striving for LM excellence through empowering people and select the best LM practice. The case study companies also inculcate LM thinking in their activities which reflected to the LM principles. Due the budget constraint, the case study companies have groomed their LM coordinator to be knowledgeable in LM and able to train their employees internally. They can be independent in LM management without engaging on a consultant. All companies agreed that the journey of LM implementation is still a long way to be accomplished. This paper has discussed the results and key findings of the case studies. It is found that the primary objective of implementing LM is to eliminate wastes through educating people and improving current system based on to the best practice as being practiced by the successful company. Though the companies have practiced different approaches and implementation, it is understood that LM has changed the way of thinking towards the elimination of wastes in every aspect. The research finding in this paper will be used for developing a framework for SME reference. This framework will hopefully be applicable within the context of Malaysian SME automotive component industry environment.

The authors wish to Automotive Excellence Centre (AEC), Universiti Malaysia Pahang (UMP), 26600 Pekan, Pahang, Malaysia for providing the financial support (Project No. RDU150339). 


\section{References}

[1] J, Rineheart, C. Huxley and D. Robertson, Just another Car Factory? Lean Production and its Contents (Cornell University Press, Ithaca, NY 1997)

[2] T.C. Papadopoulu \& M. Ozbayrak, Leanness: experiences from the journey to date, Journal of Manufacturing Tech. Mgt 16(7), 784-806(2005).

[3] R.R. Fullerton.\& C.S. McWatters, The production performance benefits from JIT implementation, J. of Operations Management, 19: 81-96(2001).

[4] J.Womack, D.T. Jones \& D. Roos, The machine that changed the world, (Rawson Associates, New York, NY 1990).

[5] S. Bhasin \& P. Burcher, Lean viewed as a philosophy, J. of Manufacturing Technology Management, 17(1): 56-72 (2006).

[6] A.M. Sanchez, \& P. Perez, Lean indicators and manufacturing strategies, Int. J. of Operations \& Production Management, 21(11): 1433-1452(2001).

[7] R. Shah, P.T. Ward 2007. Defining and developing measures of lean production. Journal of Operations Management, 25: 785-805.

[8] P. Achanga, E. Shehab, R. Roy, \& G. Nelder, Critical success factors for lean implementation within SMEs, J. of Manufacturing Technology Management, 17(4): 460-471(2006).

[9] J. A. Farris, E.M.V. Aken, T.L. Doolen, \& J. Worley, Critical success factors for human resources outcomes in Kaizen event: An empirical study. International Journal of Production Economics, 117(1): 42-65(2009)

[10] P.Y. Yang, \& Y. Yu, The Barriers to SMEs' Implementation of Lean Production and Countermeasures - Based on SMS in Wenzhou. Int. J. of Innovation, Management and Technology, 1(2): 220-225(2010).

[11] N. Nordin, Md. B. Deros, \& D.A. Wahab, A Survey on Lean Manufacturing Implementation in Malaysian Automotive. Industry, Int. J. of Innovation, Management and Technology, 1(4): 374-380(2010).

[12] A.N.M. Rose, Md. B. Deros, Abd. M.N. Rahman, Abd. M.N., Lean Manufacturing Practices Implementation in Malaysian's SME Automotive Component Industry. Applied Mechanics and Materials, 315: 686-690(2013).

[13] S.J. Pavnaskar, J.K. Gershenson, \& A.B. Jambekar, Classification scheme for lean manufacturing tools. Int. J. of Production Research 41(13): 30753090(2003).

[14] A.M.N. Rose, Md. B. Deros, Abd. M.N.Rahman, Lean manufacturing best practices in SMEs. Proceedings of the International Conference on Industrial Engineering and Operations Management (2011.

[15] R. Shah, \& P.T. Ward, Lean manufacturing context, practice bundles and performance. J. of Operations Management 21(12): 129-149(2003).
[16] A. Gunasekaran, L. Forker, \& B. Kobu, Improving operations performance in a small company: a case study. Int. J. of Operations \& Production Management 20(3): 316-335(2000).

[17] M. Kumar, \& A. Antony, Comparing the quality management practices in UK SMEs, Industrial Management \& Data Systems 108(9): 1153 1166(2008).

[18] A. Anvari, N. Zulkifli, R.M. Yusuff, S.M.H. Hojjati \& Y. Ismail, A proposed dynamic model for a lean roadmap, African Journal of Business Management 5(16): 6727-6737(2011).

[19] S. J. Pavnaskar, J. K. Gershenson, \& A.B. Jambekar, Classification scheme for lean manufacturing tools, Int. J. Production Research 41(13), 3075-3090(2003).

[20] F. Ferdousi \& A. Ahmed, An investigation of manufacturing performance improvement through lean production: A study on Bangladeshi garment firms, Int. J. of Business and Management 4(9), 106114(2009)

[21] J.E. Matson \& J.O. Matson, Just-in-time implementation issues among automotive suppliers in the southern USA. Supply Chain Management: An International Journal 12(6): 432-443(2007).

[22] R.E. White, J.N. Pearson \& J.R. Wilson, JIT Manufacturing: A Survey of implementations in small and large U.S. manufacturers, Management Science 45(1): 1-14(1999).

[23] S. Sakakibara, B.B. Flynn, R.C. Schroeder, \& W.T. Morris, The Impact of Just-In-Time Manufacturing and Its Infrastructure on Manufacturing Performance, Management Science 43(9): 12461257(1997).

[24] Y.C. Wong, K.Y. Wong, \& A. Ali, A study on lean manufacturing implementation in the Malaysia electrical and electronics industry. European Journal of Scientific Research 38(4), 521535(2009).

[25] R.K. Yin, Case study research, (Sage Publication, $2^{\text {nd }}$ edition 1994).

[26] R.E. Stake, The art of case study research, (Thousand Oaks, CA: SAGE Publications 1995).

[27] U. Flick, An Introduction to Qualitative Research (SAGE Publications 2002)

[28] A. Bryman, Social Research Methods, Oxford Publication $3^{\text {rd }}$ Edition 2008).

[29] R.K. Yin, Case Study Research: Design and Methods (Sage Publication, $3^{\text {rd }}$ edition, 2003).

[30] R.K. Yin, Case study research (Sage Publication, $1^{\text {st }}$ edition, 1989).

[31] P. Hines, M. Holweg, \& N. Rich, Learning to evolve - A review of contemporary lean thinking. Int. J. of Operations \& Production Management 24 (10), 994-1011(2004).

[32] T. Bonavia \& J.A.Marin, An empirical study of lean production in the ceramic tile industry in Spain, Int. J. of Operations \& Production Management, 26(5), 505-531(2006). 